\title{
Effect of a dual-purpose inoculant on the quality and nutrient losses from corn silage produced in farm-scale silos
}

\author{
O. C. M. Queiroz, A. T. Adesogan, ${ }^{1}$ K. G. Arriola, and M. F. S. Queiroz ${ }^{2}$ \\ Department of Animal Sciences, Institute of Food and Agricultural Sciences, University of Florida, Gainesville 32611
}

\begin{abstract}
This project aimed to determine effects of applying an inoculant containing homofermentative and heterofermentative bacteria on the fermentation, nutritive value, aerobic stability, and nutrient losses from corn silage produced in farm-scale silos. Corn forage was harvested at $34 \%$ dry matter (DM) and treated without (control) or with $5 \times 10^{5} \mathrm{cfu} / \mathrm{g}$ of Lactobacillus buchneri and Pediococcus pentosaceus. The inoculant was sprayed on alternate 8-row-wide swaths of forage, and the untreated and inoculated forages were alternately packed into 3.6-m-wide bag silos. Forty-five tonnes of corn forage were packed into each of 4 replicate bags per treatment and ensiled for $166 \mathrm{~d}$. Silage removed from the bags $(500 \mathrm{~kg} / \mathrm{d})$ was separated into good and spoiled (visibly moldy or darker) silage portions, and weighed for 35 d. Weekly composites were analyzed for chemical composition, aerobic stability, and fungal counts. Aerobic stability was measured using data loggers that recorded sample and ambient temperature every 30 min for 7 d. Inoculation did not affect the chemical composition of the spoiled or good silage but decreased the quantity ( 5.7 vs. $12.9 \mathrm{~kg} / \mathrm{d}$ ) and percentage (3.4 vs. 7.8 ) of spoiled silage in the bags by over $50 \%$. Losses of crude protein $(0.28$ vs. $0.92 \mathrm{~kg} / \mathrm{d})$, gross energy $\left(6.0 \times 10^{4}\right.$ vs. $\left.1.8 \times 10^{5} \mathrm{~kJ} / \mathrm{d}\right)$, and neutral detergent fiber $(1.34$ vs. $4.12 \mathrm{~kg} / \mathrm{d}$ ) in spoiled silage were less in inoculated versus control silages. Inoculated silages had lower $\mathrm{pH}$ (3.91 vs. 3.99), lactate concentration (7.63 vs. $7.86 \%$ ), lactate:acetate ratio (1.58 vs. $2.53 \%)$, and a greater acetate (5.11 vs. $3.56 \%$ ) concentration than the control silage. Inoculated silages tended to have fewer yeasts ( 2.59 vs. $4.62 \log \mathrm{cfu} / \mathrm{g}$ ) than control silages, but aerobic stability was not different across treatments (14.7 vs. $9.5 \mathrm{~h}$ ). Applying the inoculant made the fermentation more heterolactic, inhibited the growth of yeasts, and substantially reduced the amount of spoilage and the associated energy and nutrient losses.
\end{abstract}

\footnotetext{
Received November 29, 2011.

Accepted January 8, 2012.

${ }^{1}$ Corresponding author: adesogan@ufl.edu

${ }^{2}$ Current address: Department of Animal Sciences, Universidade
} Federal da Paraíba, Paraíba, Brazil.
Key words: silage inoculant, Lactobacillus buchneri, Pediococcus pentosaceus

\section{INTRODUCTION}

Bacterial inoculants have been used to dominate the epiphytic microbial population and thereby improve the fermentation, shelf life, and quality of silages (Filya et al., 2007; Pedroso et al., 2010). During ensiling, fermentation of sugars into lactic acid by homofermentative lactic acid bacteria, such as Pediococcus pentosaceus, causes a rapid $\mathrm{pH}$ decrease, which inhibits growth of undesirable microorganisms (Filya et al., 2006). Heterofermentative lactic acid bacteria ferment sugars into lactic acid as well as other VFA (McDonald et al., 1991). Lactobacillus buchneri is a heterofermentative bacterium capable of converting lactate to acetate, which is a potent antimycotic agent that is metabolized to a lesser extent than lactate by aerobic microorganisms (Oude Elferink et al., 2001; Kung and Ranjit, 2001). The increase in acetate due to inoculation with L. buchneri decreases the growth of spoilage-causing yeasts and molds, thereby enhancing silage aerobic stability (Kleinschmit and Kung, 2006b; Kristensen et al., 2010; Arriola et al., 2011).

Recently, dual-purpose inoculants containing homofermentative and heterofermentative bacteria have been marketed as "combo" inoculants that improve the fermentation and aerobic stability of silage. The beneficial effects of dual-purpose inoculants have been proven in numerous studies (Driehuis et al., 2001; Weinberg et al., 2002; Huisden et al., 2009). However, such studies examined silage prepared in laboratory silos. Smallscale silos offer ideal conditions for the fermentation process. They are essential tools to model the effect of inoculants on silage fermentation and aerobic stability because this approach is less costly and labor intensive compared with using farm-scale silos. Nevertheless, it is important to validate inoculant efficacy results obtained with small-scale silos in farm-scale silos because the imperfect conditions of the latter are more challenging for proper fermentation (Mari et al., 2009). In addition, the relatively small amount of silage used in mini silos hinders an accurate estimation of the long- 
term effects of inoculant application on nutrient and other losses during the aerobic feedout phase, which can last for several months on farms. Therefore, studies demonstrating inoculant efficacy using farm-scale silos are indispensable in validating the effectiveness of inoculants in mini-silo studies. Little is known about effects of dual-purpose inoculants on the fermentation of corn silage prepared using farm-scale silos, and less is known about their effects on silage quality and preservation during the feedout phase in such silos.

The objective of this study was to examine the effects of applying a dual-purpose inoculant on the fermentation, nutritive value, aerobic stability, and nutrient losses from corn silage produced using farm-scale silos. We hypothesized that inoculation would improve the fermentation and aerobic stability of the silages and reduce associated nutrient and energy losses during the feedout phase.

\section{MATERIALS AND METHODS}

\section{Silage Production}

Corn hybrid (Dekalb 69-70, Monsanto, St. Louis, $\mathrm{MO}$ ) was grown at the Dairy Unit, University of Florida (Hague), and harvested within $24 \mathrm{~h}$ from October 31, 2008, to November 1, 2008, when no rain was forecasted and average temperature was $23.0^{\circ} \mathrm{C}$. Corn was harvested at $34 \% \mathrm{DM}$ (half milk line stage) and chopped to achieve a 19-mm theoretical length of cut using a forage harvester fitted with an 8-row corn head (Claas Jaguar 980, Claas of America LLC, Columbus, IN). Corn plants were treated without (control) or with a dual-purpose inoculant (Buchneri 500; LB500 treatment) that supplied $1 \times 10^{5} \mathrm{cfu}$ of Pediococcus pentosaceous 12455 and $4 \times 10^{5}$ cfu of Lactobacillus buchneri 40788 per gram of fresh forage (Lallemand Animal Nutrition, Milwaukee, WI). To ensure that similar forage was used for both treatments, the inoculant was sprayed on alternate 8-row-wide swaths of forage with a sprayer mounted on the harvester, and the respective swaths were alternately packed into $\mathrm{Ag}$ bag silos (Ag-Bag, Miller-St. Nazianz Inc., St. Nazianz, WI) with a Versa 1012 bagger (Versa Corp., Astoria, OR). Therefore, each bag containing the control silage was filled immediately after filling the preceding one with the inoculated silage. This may have allowed minor inoculant application to the forage packed into the front of control bags; therefore, silage in the first $5 \mathrm{~m}$ from the back (unopened end) of control and inoculated bags was not used for the experiment. Inoculation and packing was completed on the same day and 4 replicate 45 -tonne bags of forage were prepared for each treatment. Three wireless sensors programmed to record temperature data hourly were placed at a height of approximately $1 \mathrm{~m}$ above ground level in each bag at distances of about 7, 14, and $21 \mathrm{~m}$ from the back of the silo during packing.

After $166 \mathrm{~d}$ of ensiling, the bags were opened and silage was removed from the face at the rate of 500 $\mathrm{kg} / \mathrm{d}$, separated into good and spoiled (visibly moldy or darker) silage portions, and weighed for $35 \mathrm{~d}$. Temperature sensors were retrieved during unloading of the silage, and the data were used to calculate average, minimum, and maximum temperatures, and time to achieve maximum temperature during ensiling.

\section{Laboratory Analysis}

Daily samples of good and spoiled silage were analyzed for DM by drying in a forced-air oven at $60^{\circ} \mathrm{C}$ for $48 \mathrm{~h}$. Additional samples were collected on d 0 , $7,14,21,28$, and 35 after opening of silage bags and immediately analyzed for yeast and mold counts and aerobic stability or stored at $-20^{\circ} \mathrm{C}$ for subsequent determination of chemical composition, fermentation product profile, and gross energy. Nutrient and energy losses were quantified as the product of the dry weight and the concentration of the nutrient in spoiled silage on days of sample collection (d 0, 7, 14, 21, 28, and 35).

Frozen weekly silage samples were thawed, dried at $60^{\circ} \mathrm{C}$ for $48 \mathrm{~h}$ in a forced-air oven, ground to pass the 1-mm screen of a Wiley mill (A. H. Thomas, Philadelphia, PA), and analyzed for DM $\left(105^{\circ} \mathrm{C}\right.$ for $\left.16 \mathrm{~h}\right)$ and ash $\left(512^{\circ} \mathrm{C}\right.$ for $\left.8 \mathrm{~h}\right)$. Concentrations of NDF and ADF were measured using the method of Van Soest et al. (1991) in an Ankom 200 Fiber Analyzer (Ankom Technologies, Macedon, NY). Heat-stable $\alpha$-amylase and sodium sulfite were used in the NDF assay. Nitrogen was determined by rapid combustion using a Macro elemental $\mathrm{N}$ analyzer (Vario MAX CN, model ID 25.00-5003; Elementar, Hanau, Germany), and CP was calculated as $\mathrm{N} \times 6.25$. Water-soluble carbohydrate concentration was determined by the anthrone reaction assay (Ministry of Agriculture, Fisheries and Food, 1986), and ammonia- $\mathrm{N}$ was measured by distillation (AOAC, 1985). An adiabatic bomb calorimeter (1261 Isoperibol, Parr Instrument Co., Moline, IL) was used to calculate the gross energy concentration of spoiled samples from both treatments.

Aerobic stability was measured on weekly samples by placing $2 \mathrm{~kg}$ of good silage in an open-top polystyrene box. Temperature sensors (Hobo temperature data logger 64 k, Onset Computer Corp., Cape Cod, MA) were place at the geometric center of each silage sample, and data were recorded every $30 \mathrm{~min}$ for $7 \mathrm{~d}$. Four additional sensors were placed in the room to record ambient temperature. Silages were covered with 2 lay- 
ers of cheesecloth to prevent drying. Aerobic stability was denoted as the length of time that elapsed before silage and ambient temperatures differed by more than $2^{\circ} \mathrm{C}$ (Huisden et al., 2009). In addition, temperature data were plotted against hours of aerobic exposure to calculate the area under the aerobic stability curve.

Silage extract was prepared by mixing $25 \mathrm{~g}$ of corn silage with $225 \mathrm{~mL}$ of $0.1 \%$ peptone water in a stomacher for $3 \mathrm{~min}$. The solution was filtered through 2 layers of cheesecloth and an aliquot was immediately used for yeast and mold counts, as described by Schmidt and Kung (2010). The pH of silage was measured using a pH meter (Corning model 12, Corning Scientific Instruments, Medfield, MA). An aliquot of $2 \mathrm{~mL}$ of silage extract was centrifuged at $2,000 \times g$ for $15 \mathrm{~min}$, and the supernatant was filtered with a $0.22-\mu \mathrm{m}$ syringe filter and used for quantification of lactic acid and VFA with an HPLC (Elite Lachrom HTA, Merck Hitachi, Tokyo, Japan) coupled to a UV detector (Merck Hitachi L-2400) set at $210 \mathrm{~nm}$. The column was a Bio-Rad Aminex HPX-87H (Bio-Rad Laboratories, Hercules, CA), with $0.015 M$ sulfuric acid mobile phase and a flow rate of $0.7 \mathrm{~mL} / \mathrm{min}$ at $45^{\circ} \mathrm{C}$ (Arriola et al., 2011).

\section{Statistical Analysis}

The experiment had a completely randomized design with 2 treatments and repeated measurements over time for each of 4 replicates per treatment. Data were analyzed with the MIXED procedure (SAS Institute Inc., Cary, NC) and a model including treatment, time, and treatment $\times$ time effects. The model included a repeated statement, and the auto-regressive (1) covariance structure was used to account for sampling from the same bag over time. Differences between means were determined using the PDIFF procedure of SAS, which differentiates means based on Fisher's F-protected least significant difference test. Significant differences were declared at $P<0.05$ and tendencies at $P \geq 0.05<0.10$.

\section{RESULTS AND DISCUSSION}

The effects of inoculation on chemical composition and quantity of silage classified as good are shown in Table 1. The quantity of good silage removed from control and inoculated silos was similar (156 vs. 159 $\mathrm{kg}$ of $\mathrm{DM} / \mathrm{d} ; P=0.23$ ); however, the proportion of good inoculated silage was greater than that of good control silage (92.2 vs. $96.6 \% ; P=0.004)$. Inoculant application did not change $(P>0.05)$ concentrations of DM (34.1 vs. $34.8 \%$ ), CP (9.47 vs. $9.55 \%$ of DM), ADF (24.9 vs. $24.0 \%$ of DM), NDF (41.3 vs. $41.7 \%$ of DM), NFC (41.1 vs. $40.7 \%$ of DM), or water-soluble carbohydrates (3.30 vs. $3.46 \%$ of DM) in good silage. Huisden et al. (2009) reported that, except for slightly decreasing the concentration of water-soluble carbohydrates, the inoculant used in this study did not affect the chemical composition of silage made in mini silos from the same corn hybrid used in this study. Mari et al. (2009) also reported that no difference existed between the chemical composition of silage made using farm-scale silos that had been inoculated without or with L. buchneri alone.

The quantity (12.88 vs. $5.69 \mathrm{~kg} / \mathrm{d} ; P=0.002)$ and proportion ( 7.83 vs. $3.39 \% ; P=0.004$ ) of spoiled silage was greater in control versus inoculated silages (Table 2 ). Therefore, the lower proportion of good silage in control versus inoculated silages was due to the greater proportion of spoiled silage in the respective silages. That inoculation reduced the quantity of spoiled silage by about $56 \%$ is important because feeding spoiled silage can predispose cows to reduced performance and

Table 1. Effect of inoculant treatment ${ }^{1}$ on the quantity and chemical composition of good silage ${ }^{2}$ removed daily from silos

\begin{tabular}{|c|c|c|c|c|c|c|}
\hline \multirow[b]{2}{*}{ Item } & \multirow[b]{2}{*}{ Control } & \multirow[b]{2}{*}{ Inoculant } & \multirow[b]{2}{*}{ SEM } & \multicolumn{3}{|c|}{$P$-value } \\
\hline & & & & Treatment & Time & $\begin{array}{l}\text { Treatment } \\
\times \text { Time }\end{array}$ \\
\hline Good silage $(\%)$ & 92.2 & 96.6 & 1.43 & 0.004 & 0.76 & 0.71 \\
\hline \multicolumn{7}{|l|}{ Chemical composition } \\
\hline $\mathrm{DM}(\%)$ & 34.1 & 34.8 & 1.26 & 0.60 & 0.11 & 0.51 \\
\hline NDF $(\%)$ & 41.3 & 41.7 & 1.57 & 0.81 & 0.12 & 0.49 \\
\hline $\operatorname{NFC}^{3}(\%)$ & 41.1 & 40.7 & 1.52 & 0.83 & 0.06 & 0.55 \\
\hline Water-soluble carbohydrates (\%) & 3.30 & 3.46 & 0.33 & 0.63 & 0.61 & 0.40 \\
\hline $\operatorname{Ash}(\%)$ & 3.45 & 3.29 & 0.12 & 0.36 & 0.60 & 0.86 \\
\hline
\end{tabular}

${ }^{1}$ Control $=$ no inoculant added; Inoculant $=1 \times 10^{5} \mathrm{cfu} / \mathrm{g}$ of Pediococcus pentosaceus and $4 \times 10^{5} \mathrm{cfu} / \mathrm{g}$ of Lactobacillus buchneri.

${ }^{2}$ Silage that was not visibly moldy, dark, heating, or slimy.

${ }^{3}$ Calculated as $\mathrm{NFC}=100-[\mathrm{CP}+$ ash + fat $(\mathrm{NRC}, 2001$ values $)+\mathrm{NDF}]$. 
Table 2. Effect of inoculant treatment ${ }^{1}$ on the quantity and chemical composition of spoiled silage ${ }^{2}$ removed daily from silos and the associated nutrient and energy losses

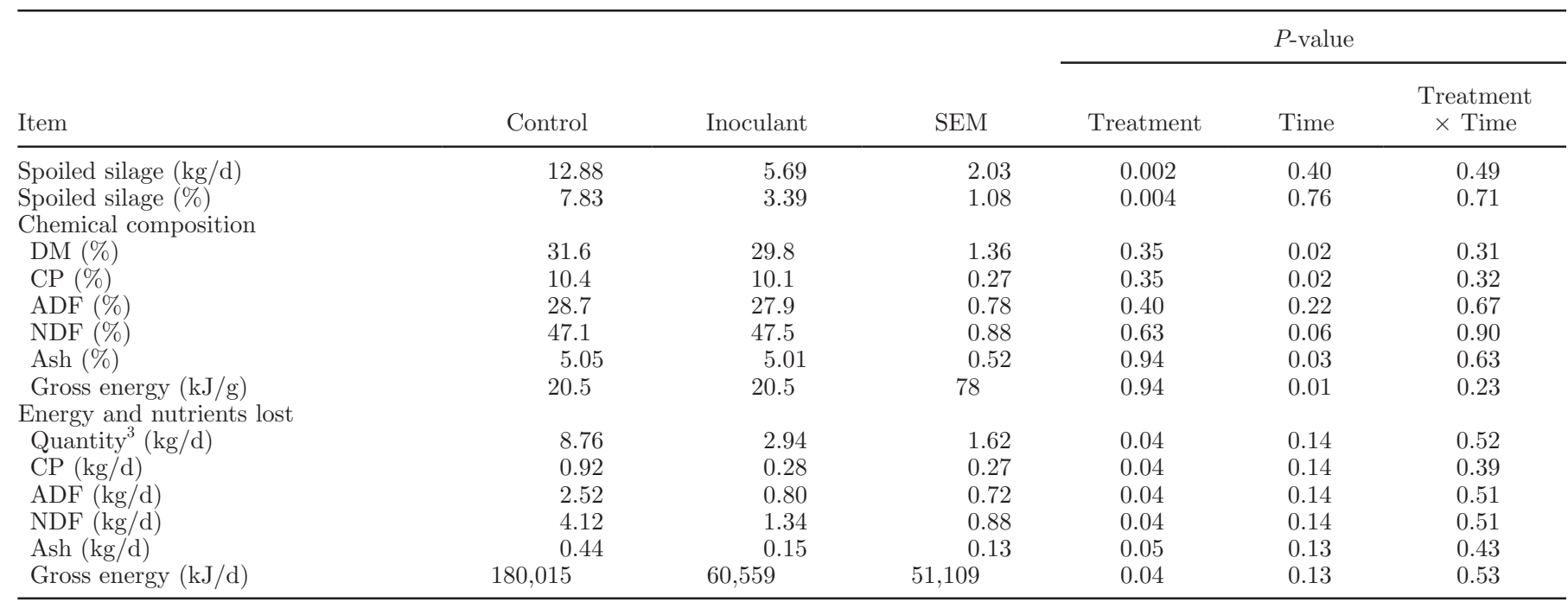

${ }^{1}$ Control $=$ no inoculant added; Inoculant $=1 \times 10^{5} \mathrm{cfu} / \mathrm{g}$ of Pediococcus pentosaceus and $4 \times 10^{5} \mathrm{cfu} / \mathrm{g}$ of Lactobacillus buchneri.

${ }^{2}$ Silage that was visibly moldy, dark, heating, or slimy.

${ }^{3}$ Quantity $=$ average amount of spoiled silage on $\mathrm{d} 0,7,12,21,28$, and 35.

increase ingestion of pathogenic organisms. Whitlock et al. (2000) reported that ingestion of increasing quantities of spoiled silage linearly reduced DMI and NDF digestibility in cattle, and Bolsen and Bolsen (2006) suggested that these reductions could reduce daily milk production by up to $1.3 \mathrm{~kg} / \mathrm{d}$. Spoiled silage can also harbor molds that directly cause diseases such as aspergillosis, farmer's lung, and hemorrhagic bowel syndrome, and indirectly cause other diseases and reduced performance via mycotoxin production (Adesogan and Queiroz, 2009). In addition, spoiled silage can contain pathogenic bacteria such as Listeria monocytogenes, Bacillus cereus, and Escherichia coli O157:H7, which can cause diseases such as meningitis, encephalitis, septicemia, gastroenteritis, mastitis, and abortions, and reduce the safety, flavor, and shelf life of dairy products (McDonald et al., 1991; Adesogan and Queiroz, 2009; Pedroso et al., 2010).

For unknown reasons, inoculated silages had a lower DM concentration than control silages $35 \mathrm{~d}$ after silos were opened (time effect, $P=0.02$; Table 2; Figure $1)$. Inoculant application did not affect $(P>0.1)$ the mean gross energy value (20.5 vs. $20.5 \mathrm{~kJ} / \mathrm{g}$; control vs. inoculant) or mean concentrations of DM (31.6 vs. $29.8 \% \mathrm{DM}), \mathrm{CP}$ (10.4 vs. $10.1 \%$ of $\mathrm{DM})$, NDF (47.1 vs. $47.5 \%$ of $\mathrm{DM}$ ), $\mathrm{ADF}$ (28.7 vs. $27.9 \%$ of $\mathrm{DM}$ ), or ash ( 5.05 vs. $5.01 \%$ of DM) in spoiled silage. Therefore, inoculation did not affect the composition of good or spoiled silages but it reduced the amount of silage that became spoiled. Consequently, inoculation reduced losses of CP (0.92 vs. $0.28 \mathrm{~kg} / \mathrm{d} ; P=0.04)$, NDF (4.12 vs. $1.34 \mathrm{~kg} / \mathrm{d} ; P=0.04), A D F(2.52$ vs. $0.80 \mathrm{~kg} / \mathrm{d} ; P$ $=0.04)$, ash (0.44 vs. $0.15 \mathrm{~kg} / \mathrm{d} ; P=0.05)$, and gross energy $(180,015$ vs. $60,559 \mathrm{~kJ} / \mathrm{g} ; P=0.04)$.

Inoculation decreased the $\mathrm{pH}$ of silages (3.99 vs. 3.91; $P=0.01)$ but all values were below the threshold $(\mathrm{pH}$ 4) that indicates adequate fermentation (McDonald et al., 1991; Table 3). Mean lactic acid concentration did not differ between control and inoculated silages (7.86 vs. $7.63 \%$ of $\mathrm{DM} ; P=0.63$ ), although that of the control silage tended to be greater $28 \mathrm{~d}$ after silo opening (inoculation $\times$ time interaction, $P=0.09$; Figure 2). Mean acetic acid concentration tended to be greater in inoculated silages (3.56 vs. $5.11 \%$ of DM; $P$ $=0.07)$; therefore, the lactate:acetate ratio tended to be lower in such silages (2.53 vs. $1.58 ; P=0.08$ ). These results were caused by a rapid increase in acetic acid concentration in inoculated silages during the first $7 \mathrm{~d}$ of the feedout phase (Figure 3) as well as a tendency for greater concentrations of the acid in inoculated versus control silages at 14 and $21 \mathrm{~d}$ (inoculant $\times$ treatment interaction, $P=0.10$; Table 3 ). That inoculation increased acetate concentration was attributable at least partly to the presence of $L$. buchneri, which ferments sugars and lactate to acetate (Oude Elferink et al., 2001). Application of L. buchneri alone to corn silages often increases acetate concentration at the expense of lactate concentration (Kleinschmit and Kung, 2006b). However, this difference is not always evident or statistically significant (Kleinschmit and Kung, 2006a; Huisden et al., 2009), as in this study. It is interesting to note that acetic acid concentrations of control 


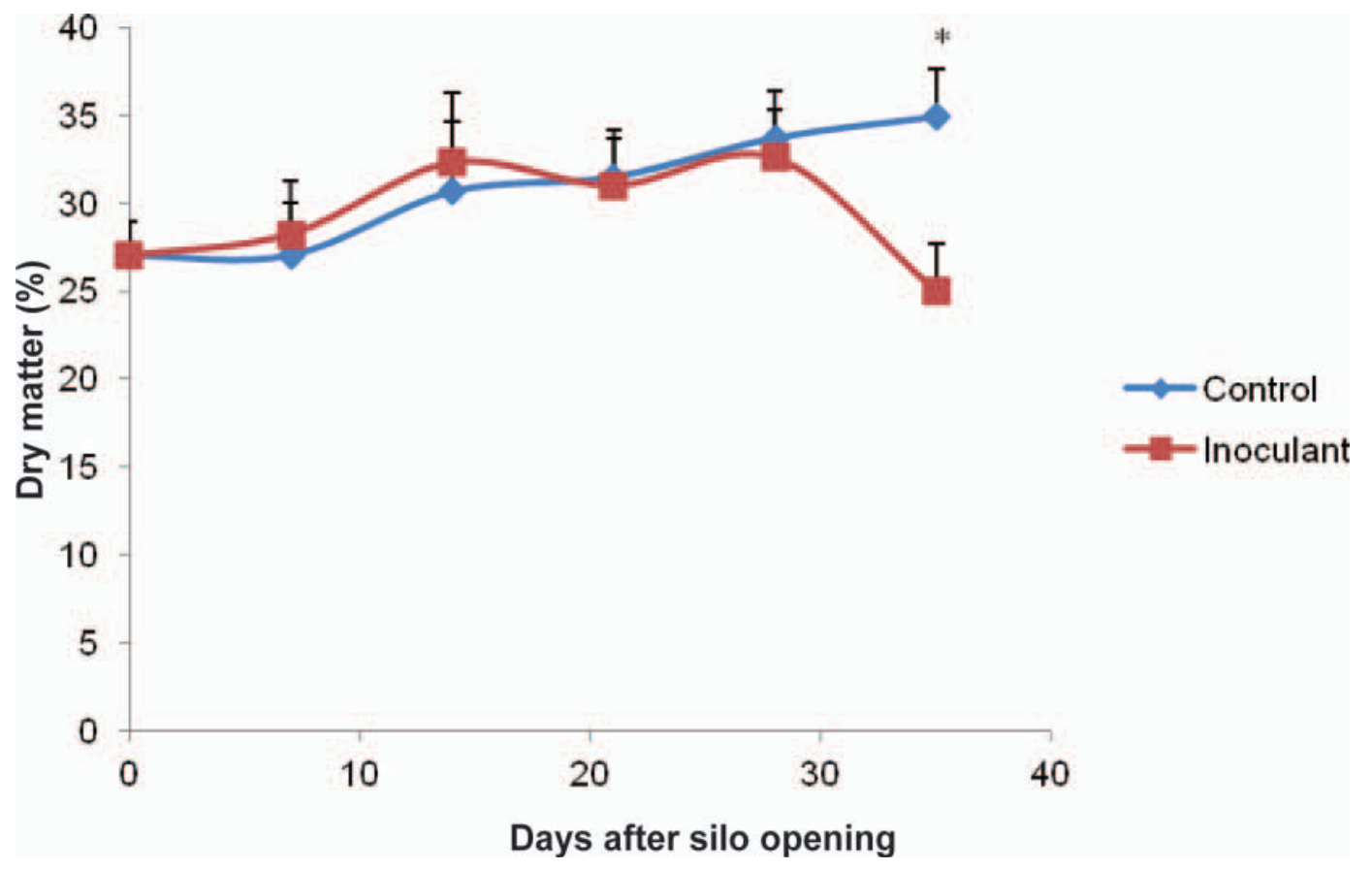

Figure 1. Changes in DM concentration of spoiled silage with time; ${ }^{*} P<0.05$. Color version available in the online PDF.

and inoculated silages did not differ statistically until $7 \mathrm{~d}$ after opening. This delay suggests that aerobic organisms may have contributed to the greater acetate production in inoculated silages because effects of $L$. buchneri on acetic acid concentrations typically occur during ensiling (Driehuis et al., 1999; Oude Elferink et al., 2001). Acetic acid bacteria can oxidize ethanol and lactate to acetate and have been suggested to initiate spoilage in corn silage in some studies (Kleinschmit and Kung, 2006b).
In addition to increasing the acetic acid concentration of silages, L. buchneri may also indirectly increase the propionic acid concentration because it can convert lactic acid into 1,2-propanediol, which is converted to propionic acid when Lactobacillus diolivorans is present (Krooneman et al., 2002). That inoculation did not affect propionic acid concentration in this study may reflect the absence of $L$. diolivorans in the silages. The concentrations of butyric acid were similar in control and inoculated silages $(0.19$ vs. $0.25 \%$ of DM; $P=$

Table 3. Effect of inoculant treatment ${ }^{1}$ on fermentation indices and temperature during ensiling in good $\operatorname{corn}_{\text {silages }}{ }^{2}$

\begin{tabular}{|c|c|c|c|c|c|c|}
\hline \multirow[b]{2}{*}{ Item } & \multirow[b]{2}{*}{ Control } & \multirow[b]{2}{*}{ Inoculant } & \multirow[b]{2}{*}{ SEM } & \multicolumn{3}{|c|}{$P$-value } \\
\hline & & & & Treatment & Time & $\begin{array}{c}\text { Treatment } \\
\times \text { Time }\end{array}$ \\
\hline $\mathrm{pH}$ & 3.99 & 3.91 & 0.20 & 0.01 & 0.04 & 0.25 \\
\hline Ammonia nitrogen ( $\%$ of DM) & 1.25 & 1.58 & 0.2 & 0.34 & 0.01 & 0.13 \\
\hline Lactic acid ( $\%$ of DM) & 7.86 & 7.63 & 0.32 & 0.63 & 0.60 & 0.09 \\
\hline Acetic acid ( $\%$ of DM) & 3.56 & 5.11 & 0.50 & 0.07 & 0.05 & 0.10 \\
\hline Lactate:acetate & 2.53 & 1.58 & 0.32 & 0.08 & 0.19 & 0.20 \\
\hline Propionic acid (\% of DM) & 0.94 & 1.10 & 0.07 & 0.17 & 0.15 & 0.86 \\
\hline Butyrate $(\%$ of $\mathrm{DM})$ & 0.19 & 0.25 & 0.06 & 0.52 & 0.70 & 0.54 \\
\hline Mean temperature $\left({ }^{\circ} \mathrm{C}\right)$ & 22.70 & 22.13 & 0.22 & 0.08 & $\mathrm{NA}^{3}$ & NA \\
\hline Maximum temperature $\left({ }^{\circ} \mathrm{C}\right)$ & 30.16 & 28.89 & 1.41 & 0.51 & NA & NA \\
\hline Minimum temperature $\left({ }^{\circ} \mathrm{C}\right)$ & 20.05 & 20.62 & 0.67 & 0.57 & NA & NA \\
\hline Range of temperature $\left({ }^{\circ} \mathrm{C}\right)$ & 10.08 & 8.27 & 1.90 & 0.76 & NA & NA \\
\hline
\end{tabular}

${ }^{1}$ Control $=$ no inoculant added; Inoculant $=1 \times 10^{5} \mathrm{cfu} / \mathrm{g}$ of Pediococcus pentosaceus and $4 \times 10^{5} \mathrm{cfu} / \mathrm{g}$ of Lactobacillus buchneri.

${ }^{2}$ Silage that was not visibly moldy, dark, heating, or slimy.

${ }^{3} \mathrm{NA}=$ not applicable. 


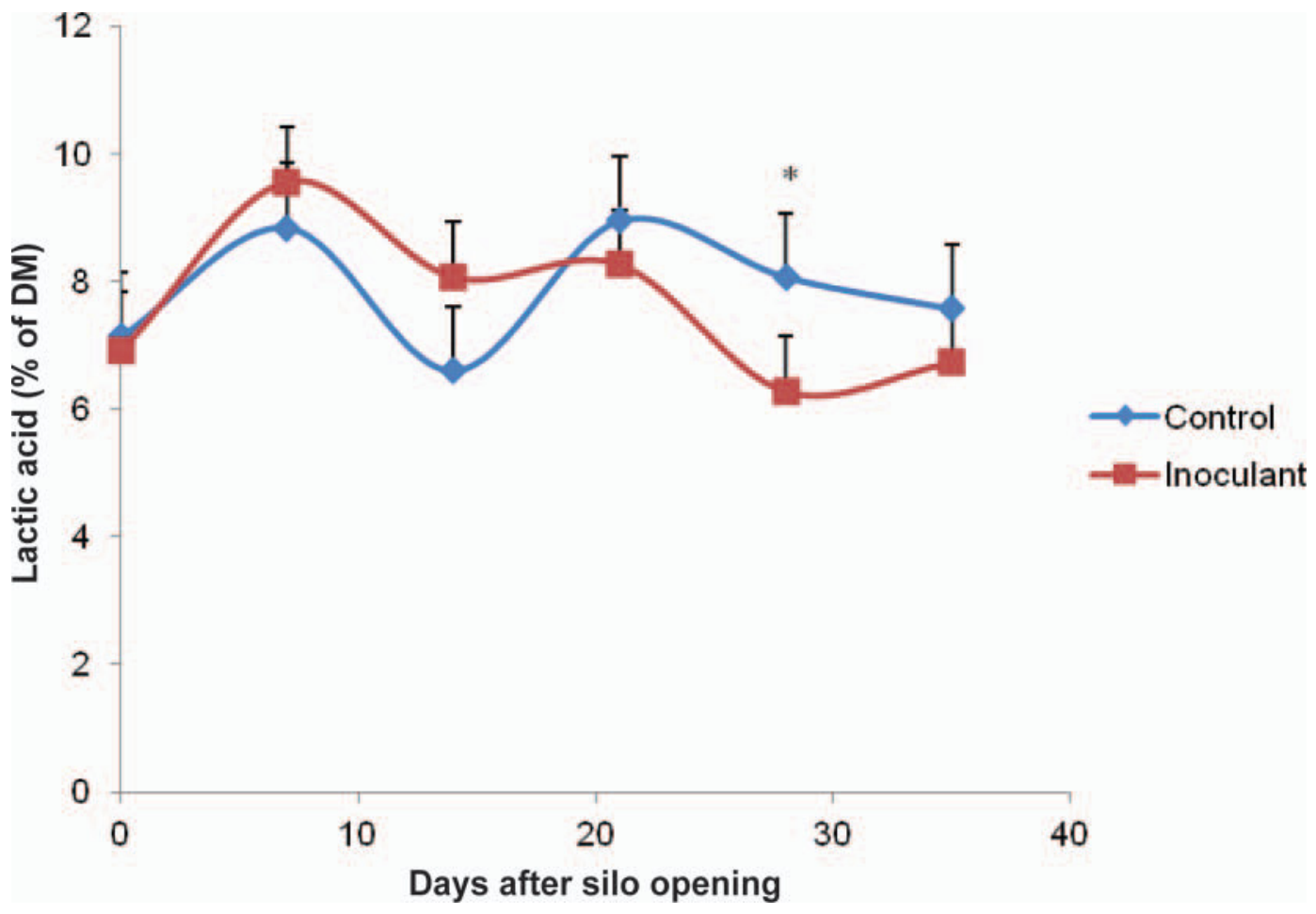

Figure 2. Changes in lactic acid concentration of good corn silage with time; ${ }^{*} P<0.05$. Color version available in the online PDF.

$0.52)$, and the values were slightly above the threshold of $0.04 \%$, which may indicate that clostridial fermentation occurred (Pahlow et al., 2003; Arriola et al., 2011).
Temperatures recorded during the fermentation were typical of those in appropriately packed and sealed silages (Kung, 2008). Maximum ensiling temperature

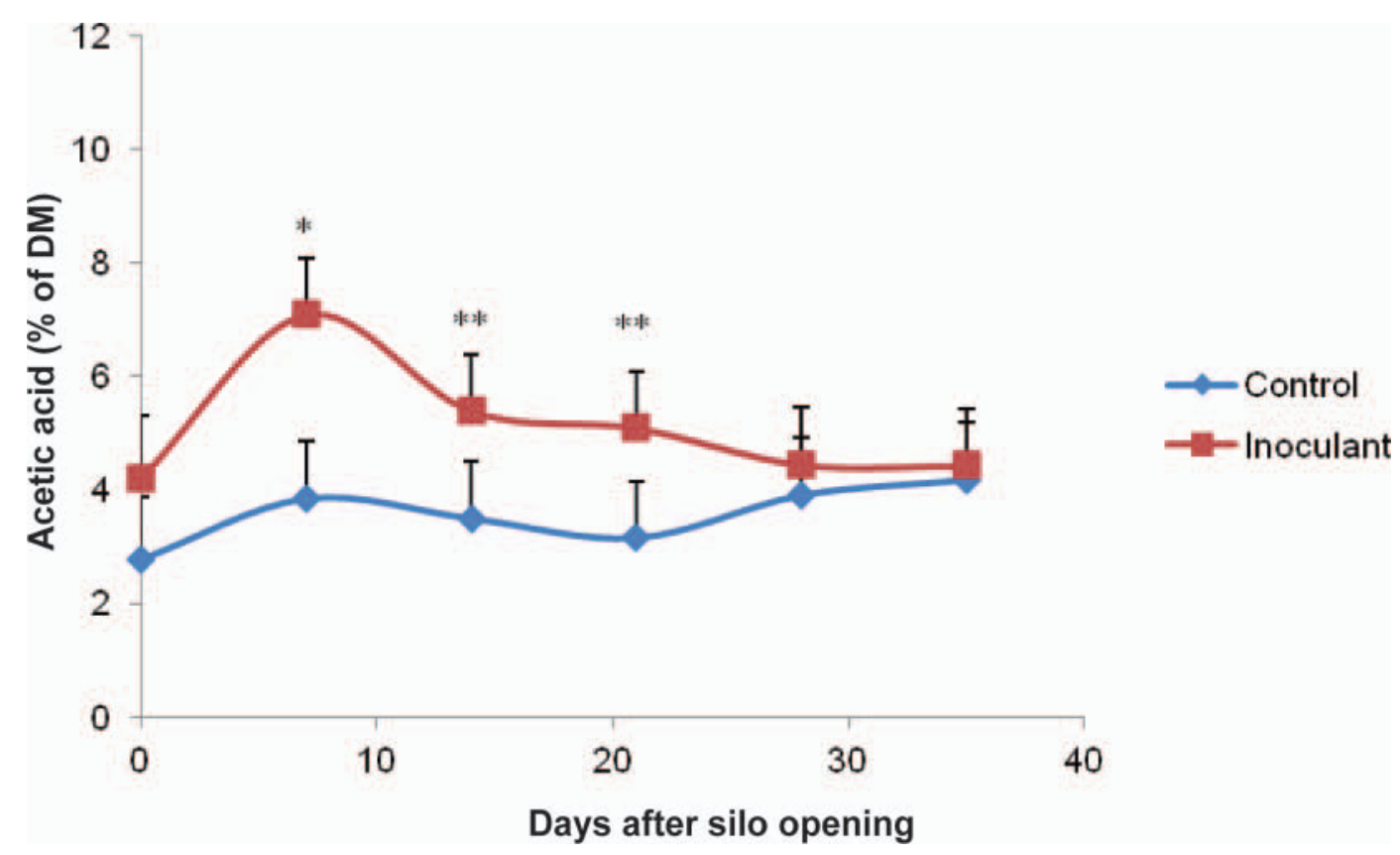

Figure 3. Changes in acetic acid concentration of good corn silage with time; ${ }^{*} P<0.05,{ }^{* *} 0.05 \leq P<0.1$. Color version available in the online PDF. 
Table 4. Effect of inoculant treatment ${ }^{1}$ on fungal counts, aerobic stability and temperature of good corn silage ${ }^{2}$

\begin{tabular}{|c|c|c|c|c|c|c|}
\hline Item & Control & Inoculant & SEM & \multicolumn{3}{|c|}{$P$-value } \\
\hline Aerobic stability $(\mathrm{h})$ & 9.5 & 14.7 & 10.6 & 0.71 & 0.63 & 0.35 \\
\hline $\begin{array}{l}\text { Area under the temperature } \\
\text { curve }\left({ }^{\circ} \mathrm{C} \times \mathrm{h}\right)\end{array}$ & 2,212 & 1,916 & 81 & 0.02 & 0.01 & $\mathrm{NA}^{3}$ \\
\hline Silo face temperature $\left({ }^{\circ} \mathrm{C}\right)$ & 36.2 & 34.8 & 1.61 & 0.42 & 0.01 & 0.98 \\
\hline
\end{tabular}

${ }^{1}$ Control $=$ no inoculant added; Inoculant $=1 \times 10^{5} \mathrm{cfu} / \mathrm{g}$ of Pediococcus pentosaceus and $4 \times 10^{5} \mathrm{cfu} / \mathrm{g}$ of Lactobacillus buchneri.

${ }^{2}$ Silage that was not visibly moldy, dark, heating, or slimy.

${ }^{3} \mathrm{NA}=$ not applicable.

did not differ between treatments $\left(30.1\right.$ vs. $28.9^{\circ} \mathrm{C} ; P=$ 0.51 ) and these temperatures were achieved within the first $3 \mathrm{~d}$ of ensiling irrespective of treatment (53.8 vs. $49.7 \mathrm{~h} ; P=0.86)$. The first 3 ensiling days represent the period when residual oxygen in the silage mass is used up by obligate and facultative microorganisms during the initial part of the aerobic phase (Pahlow et al., 2003). The minimum temperature $\left(20.0\right.$ vs. $20.6^{\circ} \mathrm{C}$; $P=0.57)$ and temperature range $\left(10.1\right.$ vs. $8.3^{\circ} \mathrm{C} ; P=$ 0.76 ) did not differ between treatments. However, mean ensiling temperature tended to be greater in control versus inoculated silages $\left(22.7\right.$ vs. $22.1^{\circ} \mathrm{C} ; P=0.08$ ), suggesting that inoculation reduced wasteful heat production from microbial activity during ensiling.

Inoculation reduced yeast and mold counts (2.59 vs. $4.62 \mathrm{cfu} / \mathrm{g}, P=0.01$; Table 4 ), likely reflecting the antifungal activity of the acetic acid, which tended to increase with inoculation. Aerobic stability was numerically but not statistically increased $(9.5$ vs. $14.7 \mathrm{~h} ; P$ $=0.71)$ by inoculation. Aerobic stability is typically increased when L. buchneri alone is applied to corn silage. Kleinschmit and Kung (2006b) used a meta-analysis based on 23 published experiments to demonstrate that application of $L$. buchneri alone increased acetic acid concentration in corn and small grain silages, reduced the yeast and mold population, and increased aerobic stability. Several subsequent studies have confirmed the efficacy of using L. buchneri inoculants to increase silage aerobic stability (Huisden et al., 2009; Mari et al., 2009). Nevertheless, a few contradictory studies exist. For instance, numerical nonstatistical increases $(P>$ 0.1 ) in aerobic stability were detected when $L$. buchneri alone or L. buchneri and P. pediococcus were applied to corn silage in a mini-silo study (Arriola et al., 2011). Similarly, inoculation with L. buchneri alone did not improve the aerobic stability of bermudagrass silage, largely because control silages had undergone a secondary clostridial fermentation, which made them stable by increasing the concentration of butyric acid (Adesogan et al., 2004). Schmidt and Kung (2010) reported that inoculation with $L$. buchneri alone improved the fermentation and aerobic stability of silages made at 3 of 5 locations, further indicating that factors other than the prevailing fungal population can influence the efficacy of L. buchneri inoculants. Such factors include the duration of ensiling and initiation of spoilage by acetic acid bacteria rather than yeasts (Pahlow et al., 2003; Kleinschmit and Kung, 2006b), high epiphytic counts of L. buchneri (Arriola et al., 2011), and differences among corn hybrids (Kang et al., 2009).

No treatment difference in aerobic stability was detected when aerobic stability was defined as the time that elapsed before silage and ambient temperatures differed by more than $2^{\circ} \mathrm{C}$. However, other important but less commonly used measures of aerobic stability warrant evaluation. For instance, spoilage bacteria and fungi produce $\mathrm{CO}_{2}$ as a fermentation byproduct (Spoelstra et al., 1988); therefore, $\mathrm{CO}_{2}$ production has been used as a measure of aerobic stability in some studies (Ashbell et al., 2002; Weinberg et al., 2011). Other studies have simply graphically illustrated changes in temperature over time for inoculated and control silages (Salawu et al., 2001; Adesogan et al., 2004). In the current study, total heat accumulation (estimated from area under the temperature curve) over time during the aerobic feedout phase was reduced by about $16 \%$ by inoculation $\left(2,212\right.$ vs. $\left.1,916^{\circ} \mathrm{C} \times \mathrm{h} ; P=0.02\right)$. This aerobic stability index is particularly useful for detecting effects of inoculation in studies where total heat accumulation over time is substantially different between control and inoculated silages, even though they start heating at approximately the same time. Maximum post-ensiling temperature ( 43.1 vs. $43.4^{\circ} \mathrm{C} ; P=0.85$ ), silo face temperature $\left(36.18\right.$ vs. $\left.34.86^{\circ} \mathrm{C} ; P=0.42\right)$, and temperature range $\left(17.6\right.$ vs. $\left.19.1^{\circ} \mathrm{C} ; P=0.32\right)$ were not affected by treatment, but minimum post-ensiling temperatures 
tended to be reduced by inoculation $\left(25.5\right.$ vs. $24.3^{\circ} \mathrm{C}$; $P=0.09)$. The short aerobic stability and discrepancy among measures of heat production and aerobic stability in the silages suggest that the inoculant was not as effective at increasing the bunk life of the silage as in other studies. This is attributable to factors such as a relatively low packing density (approximately $140 \mathrm{~kg}$ of $\mathrm{DM} / \mathrm{m}^{3}$ ) in the bags, which made it challenging to maintain a straight silo face and to achieve a feedout rate of at least 15 to $30 \mathrm{~cm}$ of silage per day (Pitt and Muck, 1993). Furthermore, the prevailing subtropical conditions, which are ideal for the growth of spoilagecausing yeasts and molds (Oude Elferink et al., 2001; Adesogan and Queiroz, 2009), may have contributed to poor aerobic stability response.

\section{CONCLUSIONS}

This study showed that application of a dual-purpose inoculant did not affect the nutritive value of good or spoiled corn silage made using farm-scale silos; however, it reduced the amount and proportion of spoiled silage by over $50 \%$, and thereby reduced the associated energy and nutrient losses from the silage. Inoculation reduced the yeast and mold populations and consequently reduced the total heat accumulation during the aerobic feedout phase. Most beneficial effects of the inoculant were attributed to its tendency to make the fermentation more heterolactic by increasing the concentration of acetate.

\section{ACKNOWLEDGMENTS}

The authors gratefully acknowledge funding for this project from Lallemand Animal Nutrition (Milwaukee, WI). The authors also thank the staff of the University of Florida Dairy Unit (Hague) for their assistance with the study.

\section{REFERENCES}

Adesogan, A. T., N. A. Krueger, M. B. Salawu, D. B. Dean, and C. R. Staples. 2004. The influence of treatment with dual purpose inoculants or soluble carbohydrates on the fermentation and aerobic stability of bermudagrass. J. Dairy Sci. 87:3407-3416.

Adesogan, A. T., and O. C. M. Queiroz. 2009. Silage pathogenicity and implications for the ruminant production chain. Pages 225241 in Proc. Int. Symp. Forage Quality and Conservation. M. Zopollato, G. B. Muraro and L. G. Nussio, ed. FEALQ, Piracicaba, SP, Brazil.

AOAC (Association of Official Analytical Chemists). 1985. Official Methods of Analysis. 14th ed. Association of Official Analytical Chemists, Washington, DC.

Arriola, K. G., S. C. Kim, and A. T. Adesogan. 2011. Effect of applying inoculants with heterolactic or homolactic and heterolactic bacteria on the fermentation and quality of corn silage. J. Dairy Sci. 94:1511-1516.
Ashbell, G., Z. G. Weinberg, Y. Hen, and I. Filya. 2002. The effects of temperature on the aerobic stability of wheat and corn silages. J. Ind. Microbiol. Biotechnol. 28:261-263.

Bolsen, K. K., and R. Bolsen. 2006. A trouble-shooter for 10 common silage problems. Pages 117-126 in Proc. 21st Annu. Southwest Nutr. Management Conf., Tempe, AZ. The University of Arizona, Tucson.

Driehuis, F., S. J. W. H. Oude Elferink, and S. F. Spoelstra. 1999. Anaerobic lactic acid degradation during ensilage of whole crop maize inoculated with Lactobacillus buchneri inhibits yeast growth and improves aerobic stability. J. Appl. Microbiol. 87:583-594.

Driehuis, F., S. J. W. H. Oude Elferink, and P. G. Van Wikselaar. 2001. Fermentation characteristics and aerobic stability of grass silage inoculated with Lactobacillus buchneri, with or without homofermentative lactic acid bacteria. Grass Forage Sci. 56:330-343.

Filya, I., R. E. Muck, and F. E. Contreras-Govea. 2007. Inoculant effects on alfalfa silage: Fermentation products and nutritive value. J. Dairy Sci. 90:5108-5114.

Filya, I., E. Sucu, and A. Karabulut. 2006. The effects of Propionibacterium acidipropionici and Lactobacillus plantarum, applied at ensiling, on the fermentation and aerobic stability of low dry matter corn and sorghum silages. J. Ind. Microbiol. Biotechnol. 33:353-358.

Huisden, C. M., A. T. Adesogan, S. C. Kim, and T. Ososanya. 2009. Effect of applying molasses or inoculants containing homofermentative or heterofermentative bacteria at two rates on the fermentation and aerobic stability of corn silage. J. Dairy Sci. 92:690-697.

Kang, T. W., A. T. Adesogan, S. C. Kim, and S. S. Lee. 2009. Effects of an esterase-producing inoculant on fermentation, aerobic stability, and neutral detergent fiber digestibility of corn silage. J. Dairy Sci. 92:732-738.

Kleinschmit, D. H., and L. Kung Jr. 2006a. The effects of Lactobacillus buchneri 40788 and Pediococcus pentosaceus R1094 on the fermentation of corn silage. J. Dairy Sci. 89:3999-4004.

Kleinschmit, D. H., and L. Kung Jr. 2006b. A meta-analysis of the effects of Lactobacillus buchneri on the fermentation and aerobic stability of corn and grass and small-grain silages. J. Dairy Sci. 89:4005-4013.

Kristensen, N. B., K. H. Sloth, O. Hojberg, N. H. Spliid, C. Jensen, and R. Thogersen. 2010. Effects of microbial inoculants on corn silage fermentation, microbial contents, aerobic stability, and milk production under field conditions. J. Dairy Sci. 93:3764-3774.

Krooneman, J., F. Faber, A. C. Alderkamp, S. J. H. W. Oude Elferink, F. Driehuis, I. Cleenwerck, J. Swings, J. C. Gottschal, and M. Vancanneyt. 2002. Lactobacillus diolivorans sp. nov., a 1,2-propanediol-degrading bacterium isolated from aerobically stable maize silage. Int. J. Syst. Evol. Microbiol. 52:639-646.

Kung, L., Jr. 2008. Silage temperature: How hot is too hot? Dairy Newsletter. Accessed May 10, 2011. http://www.qualitysilage. com/silage-troubleshooting/PDF/SilageTemps-How-Hot-is-TooHot.pdf.

Kung, L., Jr., and N. K. Ranjit. 2001. The effect of Lactobacillus buchneri and other additives on the fermentation and aerobic stability of barley silage. J. Dairy Sci. 84:1149-1155.

Mari, L. J., R. J. Schmidt, L. G. Nussio, C. M. Hallada, and L. Kung. 2009. Short communication: An evaluation of the effectiveness of Lactobacillus buchneri 40788 to alter fermentation and improve the aerobic stability of corn silage in farm silos. J. Dairy Sci. 92:1174-1176.

McDonald, P., N. Henderson, and S. Heron. 1991. The Biochemistry of Silage. 2nd ed. Chalcombe Publications, Bucks, UK.

Ministry of Agriculture, Fisheries, and Food. 1986. The Analysis of Agricultural Materials. Reference book 427. HMSO, London, UK.

NRC. 2001. Nutrient Requirements of Dairy Cattle. 7th rev. ed. Natl. Acad. Sci., Washington, DC.

Oude Elferink, S. J. W. H., J. Krooneman, J. C. Gottschal, S. F. Spoelstra, F. Faber, and F. Driehuis. 2001. Anaerobic conversion of lactic acid to acetic acid and 1,2-propanediol by Lactobacillus buchneri. Appl. Environ. Microbiol. 67:125-132.

Pahlow, G., R. E. Muck, F. Driehuis, S. J. W. H. Oude Elferink, and S. F. Spoelstra. 2003. Microbiology of ensiling. Pages 31-93 in 
Silage Science and Technology (Agronomy Series No. 42). D. R. Buxton, R. E. Muck, and H. J. Harrison, ed. American Society of Agronomy, Madison, WI.

Pedroso, A. F., A. T. Adesogan, O. C. M. Queiroz, and S. K. Williams. 2010. Control of Escherichia coli O157:H7 in corn silage with or without various inoculants: Efficacy and mode of action. J. Dairy Sci. 93:1098-1104

Pitt, R. E., and R. E. Muck. 1993. A diffusion model of aerobic deterioration at the exposed face of bunker silos. J. Agric. Eng. Res. $55: 11-26$.

Salawu, M. B., E. H. Warren, and A. T. Adesogan. 2001. Fermentation characteristics, aerobic stability and ruminal degradation of ensiled pea/wheat bi-crop forages treated with two microbial inoculants, formic acid or quebracho tannins. J. Sci. Food Agric. $81: 1263-1268$.

Schmidt, R. J., and L. Kung Jr. 2010. The effects of Lactobacillus buchneri with or without a homolactic bacterium on the fermentation and aerobic stability of corn silages made at different locations. J. Dairy Sci. 93:1616-1624.
Spoelstra, S. F., M. G. Courtin, and J. A. C. Van Beers. 1988. Acetic acid bacteria can initiate aerobic deterioration of whole crop maize silage. J. Agric. Sci. 111:127-132.

Van Soest, P. J., J. B. Robertson, and B. A. Lewis. 1991. Methods for dietary fiber, neutral detergent fiber and non-starch polysaccharides in relation to animal nutrition. J. Dairy Sci. 74:3568-3597.

Weinberg, Z. G., G. Ashbell, Y. Hen, A. Azrieli, G. Szakacs, and I. Filya. 2002. Ensiling whole-crop wheat and corn in large containers with Lactobacillus plantarum and Lactobacillus buchneri. J. Ind. Microbiol. Biotechnol. 28:7-11.

Weinberg, Z. G., P. Khanal, C. Yildiz, Y. Chen, and A. Arieli. 2011. Ensiling fermentation products and aerobic stability of corn and sorghum silages. Grassl. Sci. 57:46-50.

Whitlock, L. A., T. J. Wistuba, M. K. Seifers, R. V. Pope, and K. K. Bolsen. 2000. Effect of level of surface-spoiled silage on the nutritive value of corn silage diets. J. Dairy Sci. 83(Suppl. 1):110. (Abstr.) 